\title{
Intergenerational Differences in Memories of Yugoslavia - the Case of Slovenia
}

\author{
Katja Vintar Mally ${ }^{\mathrm{A}}$, Tatjana Resnik Planinc $\mathrm{A}^{*}$ \\ Received: March 31, 2019 | Revised: June 23, 2019 | Accepted: June 24, 2019 \\ DOI: $10.5937 / g p 23-21233$
}

\begin{abstract}
Over the 50-year history of Yugoslavia, there were rises and falls, successes and failures, bright and dark moments. It is thus not surprising that the many memories that people have of life in Yugoslavia are often diametrically opposed. These divergent memories of Yugoslavia are the central topic of our research. The study focuses on memories and their transmission from older to younger generations and is based on the results of a survey that was carried out in the Republic of Slovenia. The research has clearly shown that positively tinged memories of Yugoslavia predominate in the families of younger as well as older generations on the one hand while on the other hand it has become obvious that Yugonostalgia is nostalgia for something from the past and it is not a desire to experience or revive that in the present.
\end{abstract}

Keywords: memories; nostalgia; breakup of Yugoslavia; intergenerational differences in Yugonostalgia

\section{Introduction}

Over the 50-year history of Yugoslavia, a country founded in November 1943 and officially dismantled in January 1992, there were rises and falls, successes and failures, bright and dark moments. It is thus not surprising that the many memories that people have of life in Yugoslavia are often diametrically opposed. Whereas in Slovenia some remember it as a country whose inhabitants lived a good life free of worry, others recall the shortages and the repression of political and economic freedom of individuals and nations. These divergent memories of Yugoslavia are the central topic of our research. Specifically, we focus on a comparison between members of the younger generation in the age group 15 to 30 years (i.e. the generation that was born during or after the collapse of the common state and has no direct experience of it) and representatives of the generation of their parents and grandparents, older than 30 years of age. We were interested in the types of memories of Yugoslavia that predominated in each group, how often these memories were evoked in everyday life, and who most often hands down these memories from the older to the younger generation.

The article is divided into three parts. The introduction is followed by a presentation of the theoretical and methodological framework for the study, in which the concept of nostalgia is described in more detail and critically evaluated. The section on results and their discussion presents the findings of a survey of younger and older generations that was conducted in Slovenia, through which we were able to address the research questions outlined above. In the last part we provide some key findings and concluding thoughts.

\footnotetext{
A University of Ljubljana, Faculty of Arts, Department of Geography, Aškerčeva 2, 1000 Ljubljana, katja.vintarmally@ff.uni-lj.si; tatjana.resnik@ff.uni-lj.si

* Corresponding author: Tatjana Resnik Planinc, e-mail: tatjana.resnik@ff.uni-lj.si; Tel: 003861241 1238/1230
} 


\section{Theoretical and methodological framework of the study}

The study focuses on memories and their transmission from older to younger generations, living in Slovenia. We take as our point of departure the findings of recent studies noting the variability of memories and the significance of the broader context in which the process of remembering takes place. Critical approaches to the study of memories contradict the general belief that they are permanent, accurate, and unchanging, like a video of the past stored in our brains and accessible anytime. In Lowenthal's opinion (2015) memory "does not passively record the past but actively - and errantly - reconstructs it," which means that based on individual fragments and information memories come to a conclusion about the whole. Consequently memories are often inaccurate or even made up. Nevertheless, despite the fact that the reshaping of the past is inseparably connected with the process of remembering it, we tend not to doubt memories since we believe that "eyewitness status" lends them the required legitimacy. On the other hand, Loftus and Hoffman argue that "when people do not have an original memory, they can and do accept misinformation and adopt it as their own memory" (Loftus \& Hoffman, 1989).

The present and the past are inextricably interlinked in memories, and memories are strongly dependent on the wider context in which we recall them. What and how we remember something depends heavily on when, where, and why we rekindle certain memories. According to Zerubavel there is "relatively unexplored intellectual terrain made up of various remembrance environments lying somewhere between the purely personal and absolutely universal" (Zerubavel, 1996). Moreover, an individual's memory of a particular event can change depending on the broader circumstances that triggered the memory. Likewise, memories and the past have a strong influence on our perception of the present. Everything we experience today we place within the framework of our memories. Every individual shapes his or her present expectations, aspirations, and goals with the help of the past. In the literature relating to the study of memories we can often find a division into individual and collective memories (Fentress \& Wickham, 1992; Olick \& Robbins, 1998; Lowenthal, 2015). More recent studies point out that the border between collective and individual memories is unclear and frequently blurred while Wertsch and Roediger (2008) even state that a shared understanding of what the term "collective memory" means is only beginning to emerge. Although memories are inseparably tied to the individual, it nevertheless happens that certain memories that we think are triggered by our personal experience are in fact acquired from others (Halbwachs, 2001; Lowenthal, 2015). The reason for this can be found in the fact that individual memories are much harder to preserve and revive than collective memories (Halbwachs, 2001). People therefore often collectivize individual memories or adapt them to a wider collective memory.

In interpreting the results of the study conducted we need to acknowledge that memories do not represent an objective recording of events but rather are selective, constantly changing reconstructions of the past that are adapted to the broader collective memory. Due to a close connection between the present and the past in the process of remembering, it is essential to also consider the broader context in which our study was conducted, since we expect that the negative economic, social, and political effects caused by the last economic crisis in Slovenia had a significant role in the formation and transmission of memories of Yugoslavia to the generations that were included in the study.

In addition to a critical approach to the study of memories it was also essential to include in this study of memories of Yugoslavia the concept of nostalgia and Yugonostalgia, in which nostalgia must be understood as a cultural practice through which critiques of the present are formed (Todorova \& Gille, 2010). It is important to realize that nostalgia in the past was often treated as the conceptual opposite of progress, as something reactionary, sentimental, and melancholic, a discouraged retreat from the present and a lack of faith in the future (Pickering \& Keightley, 2006).

Nostalgia is a feeling of pleasure and also slight sadness when you think about things that happened in the past (Internet 1), a wistful or excessively sentimental yearning for the past or some parts of it (Internet 2) or "1) a yearning for home or homeland (homesickness); 2) a powerful, wistful desire for something that a person had or felt in the past" (Internet 3). Etymologically, the meaning of nostalgia comes from the Greek (nostos: to return home; algos: pain, longing), and to the original meaning of homesickness was later added the meaning of a special relationship to the past. The term nostalgia itself was first used by the Swiss student of medicine Johannes Hofer in 1688 to describe the pain that he observed in Swiss soldiers who fell ill due to severe homesickness (Kiser Anspach, 1934). By the late 19th century nostalgia was no longer just a medical condition but rather "a feeling that any healthy person can experience, connected with a fond memory (usually from childhood), event, feeling, or particular object” (Marušič Kos, 2016). 
Memories and nostalgia are not equivalent. Thus Davis (1979) emphasizes that we can remember something without feeling nostalgic about it. Nostalgia is a memory with a strong conviction that something in the past was better than it is today. In nostalgia bad, unpleasant, unhappy memories are completely pushed aside, or, as Davis notes, "nostalgia is memory with the pain removed" (Davis, 1979). Nostalgia can thus be associated with personal or collective memory, which are closely interlinked (Marušič Kos, 2016); in this regard, Halbwachs (2001) emphasizes that every memory is the product of the collective even when it originates in personal experience. And indeed just in the last decade we have witnessed a renewal of collective and individual memories of the socialist period taking place in the majority of former communist countries. Post-socialist nostalgia has received a lot of attention among some researchers (Velikonja, 2004, 2008b; Luthar \& Pušnik, 2010; Todorova \& Gille, 2010; Petrović, 2013; Todorova, Dimou \& Troebst, 2014), whereas Western observers have often viewed it with disdain, regarding it as a negative, reactionary phenomenon. However, in so doing they neglect the context in which it has emerged. Its appearance is no accident, since it is closely connected with the post-transition context, and it coincided with the inclusion of eight formerly socialist countries in the European Union. This inclusion represented the symbolic end of the political and economic transition in Central and Eastern Europe. Through this inclusion the formerly communist countries once again became part of the "European family" (Rogelj, 2006). The new conditions have facilitated a different view of the past. Whereas in the 1990s any sort of evocation of memories about socialist times was met with many criticisms and treated as a non-European act, after 2004 it became somewhat more acceptable. Something similar also happened in Slovenia. The political atmosphere during the initial period after independence was exceptionally unfavorable towards anything Yugoslav. Conditions began to change after 2000 , when there was a normalization of relations among the former republics and when it became clear that Slovenia would be included in the first expansion of the European Union into Central Europe (Rogelj et al., 2017).

The rise of post-socialist nostalgia was influenced even more by the process of economic transition. This left many citizens with a feeling of loss. Nostalgia usually appears when the present condition is experienced as being worse than the previous one (Velikonja, 2008a). Besides feeling a loss of security, stability, and prosperity, people were also affected by the loss of solidarity and certain forms of social life, and the vulgarisation of cultural life (Todorova \& Gille, 2010). In this regard it is interesting that the feelings men- tioned were present not only among older generations and people whose economic position was significantly worsened as a result of the economic transition: classes of people who had gained the most economically from the transition were also frequently disappointed (Wieliczko \& Zuk, 2003). The emergence of post-socialist nostalgia coincided with a more critical attitude towards the transition process. The economic crisis that has affected Europe in the past decade has further increased the feeling of uncertainty and additionally undermined faith in a better tomorrow, thereby reinforcing post-socialist nostalgia (Rogelj et al., 2017).

In the Slovenian context post-socialist nostalgia is usually labeled with the term Yugonostalgia or "red" nostalgia, within which nostalgia for the former president of the country, Josip Broz Tito, has a special place; Velikonja calls this Titostalgia (Velikonja, 2008a). The first instances of the public manifestation of Yugonostalgia appeared soon after Slovenian independence, when so-called Balkan parties were very fashionable, while in the more recent period it can be linked to people's growing dissatisfaction with the situation in the country (Rogelj et al., 2017). Yugonostalgia today, more than a quarter century after the first instances of its public manifestation, remains an extremely complex and diverse concept, which can be defined generally as a yearning for the period of socialist Yugoslavia.

Methodologically the research is based on the results of a survey that was carried out in the Republic of Slovenia in the spring of 2016 among representatives of the younger generation in the age group 15-30 years and representatives of the generation of their parents and grandparents, older than 30 years. A total of 336 respondents participated in the survey, of which 116 were in the younger group and 220 in the older group. The average age of the younger group was 21.3 years and the average age of the older group of respondents was 56.1 years. It is important to emphasize that a large majority $(80 \%)$ of the respondents in the younger group were younger than 25 , meaning that they were born after the declaration of Slovenian independence and therefore have no personal experience of life in Yugoslavia. In both age groups as well as overall there was equal gender representation $(50.6 \%$ were women and $49.4 \%$ were men). We analyzed respondents' family connections with the republics of former Yugoslavia as an influential factor and found that only a third of the respondents had relatives in the territory of the former Yugoslavia and that the parents of only a few (8\%) had emigrated from there to Slovenia.

The survey was composed of four sets of questions. In the first set we were interested in associations with the word Yugoslavia and respondents' perceptions of the positive and negative aspects of the former com- 
mon state. In the second set we were interested in their sources of information about Yugoslavia and the types and frequency of topics talked about in families. The third set elicited information about the frequency of family conversations about certain groups of topics, the orientation of memories (positive or negative) in connection with these topics, an evaluation of the quality of life in Yugoslavia in comparison to today (in the older group based on personal experience and in the younger group according to the testimony of older generations), and the predominant traces of the Yugoslav past that respondents still encounter today. The last part of the survey included standard demographic questions.

\section{Results and discussion}

Through a survey of younger and older generations we wanted to investigate both the general state of memories of Yugoslavia as well as intergenerational differences in the memories of the younger generation compared to those of the older. The initial associations with the word Yugoslavia already revealed many overlapping points of memory among older and younger people as well as important differences. The most frequent association was Tito ( $63 \%$ of respondents), followed by the mention of various national symbols, holidays, and organizations of Yugoslavia (for example, Youth Day, the coat of arms, the flag, Pioneers, the Relay of Youth, the Party, etc.) among more than half of respondents $(52 \%)$. It was in these kinds of mentions that the greatest divergences were shown, since Tito was mentioned by a significantly greater proportion of younger respondents (75\%) compared to older ones $(57 \%)$, whereas a greater proportion of older respondents (62\%; younger only $34 \%)$ mentioned national symbols, holidays, and organizations. The older generation on average also mentioned a greater total number of associations, and these were more varied in terms of content. The older group more frequently highlighted cooperation and unity in the former state ( $41 \%$ of older and $15 \%$ of younger) and a welfare state ( $27 \%$ of older and $10 \%$ of younger), and as expected they recalled "better times" with fewer cares and less stress, their childhood and youth, and their military service in the Yugoslav Army. On the other hand the associations of the younger group were tied in greater proportion to descriptions of Yugoslavia as a political creation (35\% of younger and $19 \%$ of older), the repression of political rights and civil liberties ( $16 \%$ of young and $8 \%$ of older) and more general geographical observations (most frequently Belgrade and the Balkans). Less than a tenth of respondents mentioned associations connected with sports, culture, economic development, Yugoslavia's reputation in the world, and similar.

In the following part of the survey, respondents listed as many aspects as they liked that they recalled about Yugoslavia, placing each in a positive or negative category based on their own judgment. An interesting finding is that on average they remembered more pos- itive aspects (3.7 per respondent) than negative ones (2.5 per respondent) regarding life in Yugoslavia. The grouping of responses into categories groups (i.e. coding of responses) showed that the majority of positively mentioned aspects (Figure 1) for both younger and older participants were based on socio-economic conditions in Yugoslavia. In both groups, the most common responses were those which highlighted a good economic status, including a high level of employment, affordable credit, low prices, a large common market, higher standard of living, etc. Older respondents more often emphasized greater social security, especially to do with the functioning of the educational and health system, housing policy, rights gained thanks to unions, and greater equality among people. Both groups of respondents often mentioned comparatively better relations in the society of that time, in which there was reportedly greater coherence, solidarity, a more relaxed atmosphere, unity, and commonly pooled efforts to make progress. In addition, many emphasized the international reputation of $\mathrm{Yu}$ goslavia, including its political power and sporting accomplishments. Responses of the respondents which listed positive views of the political order (altogether $6 \%$ ) and president Tito (altogether 1\%) could be interpreted in part as nostalgia for the former political system, but these occurred more frequently among the younger generation than that of their parents and grandparents.

On the other hand, political conditions and the suppression of political rights and civil liberties were the most frequently cited negative aspects of Yugoslavia (e.g. summarizing the responses of the younger and older generations, political conditions are mentioned 189 times (23\% of all responses). The field of political rights and civil liberties shows the same result (23\% of all responses)). Examples of suppression of political rights and civil liberties were more often given by younger respondents, whereas older respondents stressed the weaknesses of the political system, socialism, communism, the one-party system, persecution of political opponents and similar. Right after political conditions, the lowest rated were economic conditions, more often by older respondents, who recall mainly the 


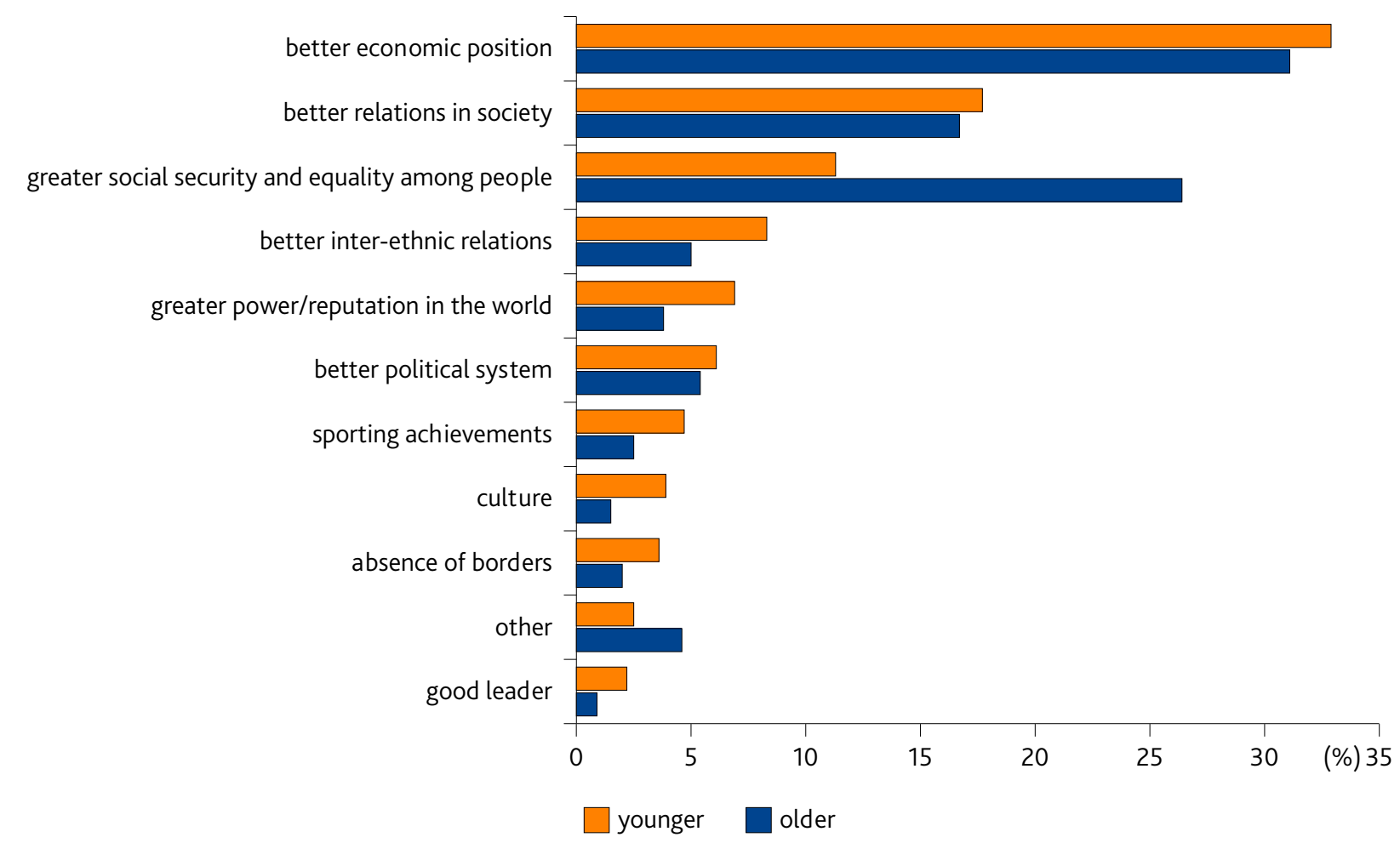

Figure 1. Views of younger and older respondents of the positive aspects of Yugoslavia

lack of material goods, as well as inflation, debt, the lagging behind of the economy, and uneven economic growth. Another significant finding is that the memory of the negative effects of centralism (with domination by Belgrade and anti-Slovenian politics), as well as conflicts and disagreement between ethnic groups, especially during the disintegration of Yugoslavia, was largely passed on to younger generations. The generalized picture shows that positively tinged memories of economic status and relations within Yugoslav society on the one hand and negatively tinged memories of the political conditions and conflicts on the other were transmitted more intensely to younger generations.
As expected, when asked about the main source of their information about Yugoslavia, older respondents primarily cited personal experience $(74 \%)$ as well as school (12\%) and relatives (8\%). In the younger group, almost three-fourths of respondents cited either their parents $(45 \%)$ or grandparents $(27 \%)$, whereas apparently school (20\%) and other sources (media, friends, other relatives) were of secondary importance in the transfer of information about Yugoslavia. These findings confirm our initial assumption, on which the study was based, that family memories about Yugoslavia are one of the key factors in the formation of the perceptions of the younger generation and in the

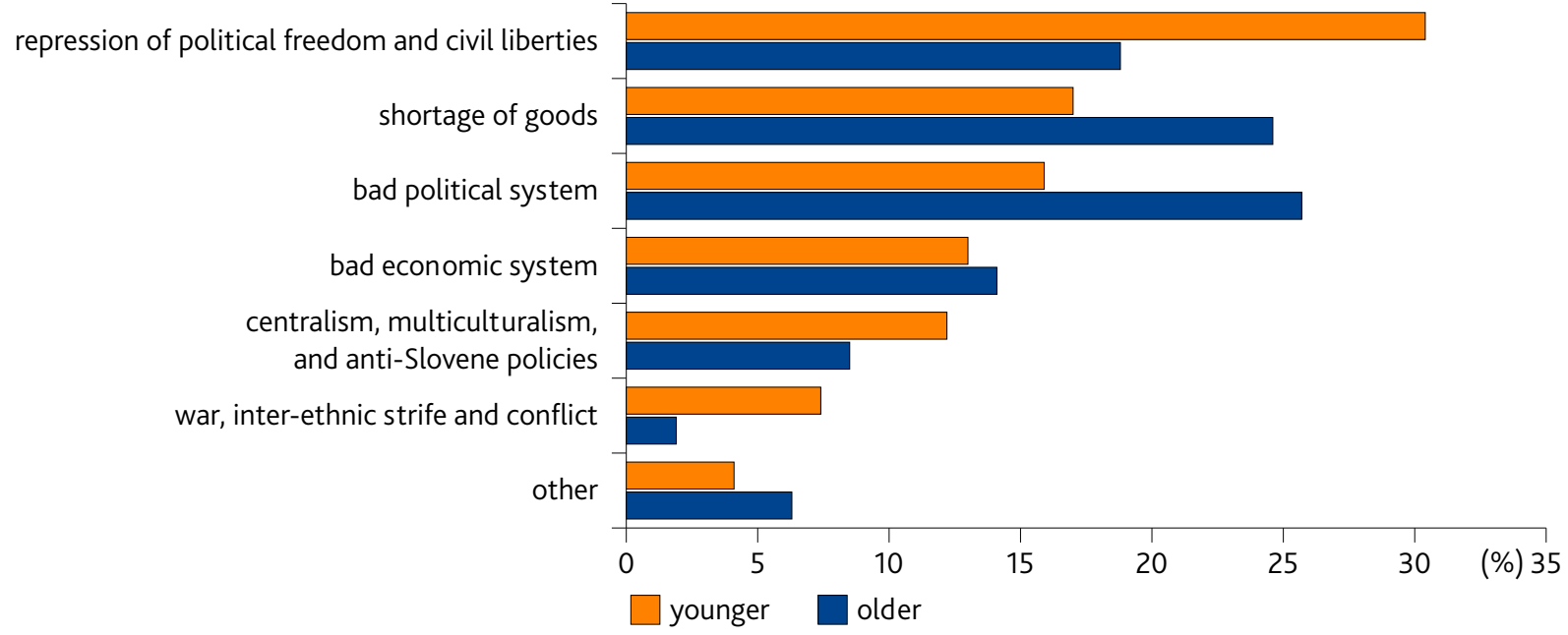

Figure 2. Views of younger and older respondents of the negative aspects of Yugoslavia 
transfer of Yugonostalgia from older to younger generations.

Based on the results of our study, discussions about Yugoslavia are occasional $(33 \%)$ or frequent $(12 \%)$ in $45 \%$ of families of the respondents younger than 30 years old, and only $14 \%$ of the families never talk about these topics. In the older group, these discussions are absent in $4 \%$ of the families while as many as $68 \%$ of respondents judge that the topic of Yugoslavia comes up occasionally (48\%) or frequently $(20 \%)$. In families of younger respondents, discussions about Yugoslavia are most frequently initiated by parents $(40.7 \%)$ or grandparents (40.7\%); only rarely do respondents themselves (9.3\%) bring up the topic. This coincides with the statements of older respondents, who acknowledge that they or their partners $(38.7 \%)$ most frequently begin the conversation, frequently also parents (19.5\%) or other older individuals in the broader family or group of friends. Older respondents stated that younger individuals (children, grandchildren) initiate the topic only $5 \%$ of the time, which underscores the role of older generations in the family and in society in general when it comes to preserving memories and passing them down to younger generations. Younger respondents answered the open question of which topic they most often talk about with their family members by stating topics connected with everyday life in Yugoslavia (42\%), the politics and political conditions of the time (18\%), personal experience of family members (13\%), wars and conflicts (7\%), and sports ( $4 \%)$.

In the continuation, we asked respondents to evaluate how often they discuss certain types of topics in the family (Figure 3) and to what extent positive or negative memories are associated with them (Figure 4). In general, it is the case that the topics provided are more often discussed in the families of older respondents who, based on their own personal experience, apparently more often compare current and past circumstances and are likely more aware of recollections. In terms of frequency, topics in the area of social and economic conditions are relatively equally represented ( $41 \%$ of families of younger respondents and $52 \%$ of families of older respondents discuss them frequently or very frequently), as are recollections of experiences of family members from the time of Yugoslavia (40\% of families of younger respondents and $53 \%$ of families of older respondents reminisce about them frequently or very frequently), especially memories of serving in the army, holidays, travels, and so on. In the families of older respondents, topics relating to the achievements of Yugoslav athletes are considerably more popular, as these memories are frequently or very frequently recalled in $49 \%$ of families, whereas in the group of younger respondents this occurs in only $29 \%$ of families. The findings also show that sporting accomplishments are one of the more minor elements of Yugonostalgia based on the initial associations as well as the intensity of transferring these memories to younger generations (as respondents themselves perceive them in their own families). Nevertheless, memories of sporting accomplishments are distinctively positive $-71 \%$ of younger and $79 \%$ of older respondents characterized them as positive or very positive, which is the highest percentage of all the topics. A different picture emerges when it comes to po-

politics and political conditions in Yugoslavia - younger

politics and political conditions in Yugoslavia - older

social and economic conditions in Yugoslavia - younger

social and economic conditions in Yugoslavia - older

sporting achievements of Yugoslav athletes - younger

sporting achievements of Yugoslav athletes - older

experiences of family members from Yugoslav times - younger

experiences of family members from Yugoslav times - older

other topics - younger

other topics - older
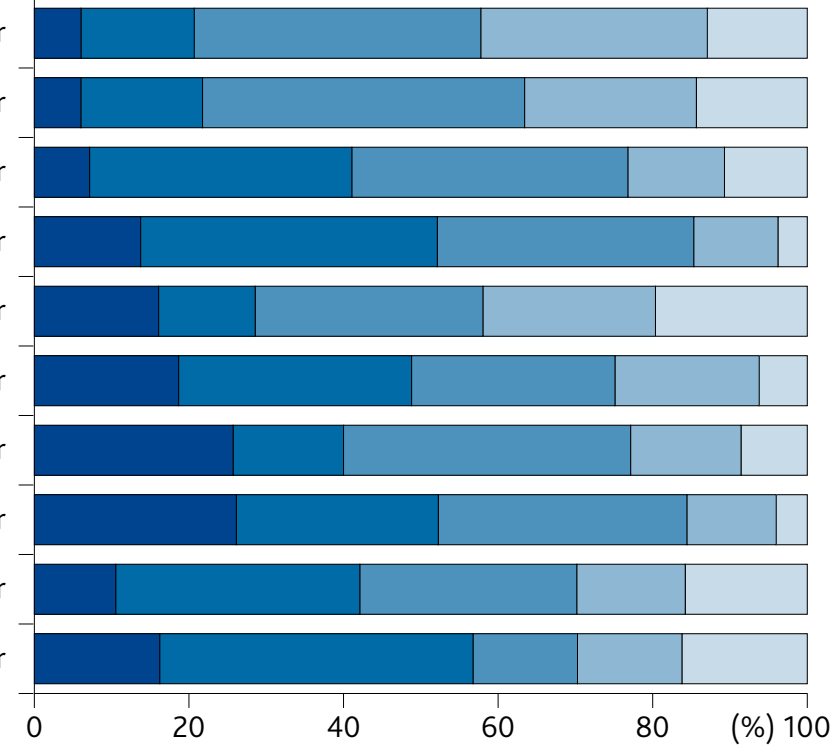

very frequently

frequently

occasionally

rarely

never

Figure 3. Assessment of the frequency of conversations about selected topics in the families of older and younger respondents 
litical topics: based on the statements of the respondents, around $42 \%$ of families of younger individuals and $36 \%$ of families of older individuals never or rarely discuss Yugoslav politics and political conditions, which is a large and surprising amount in comparison to the frequency of politically tinged associations from the introductory survey question.

While political conditions are one of the main criticisms and associations of the former country, this topic stands out with respect to negative memories: $32 \%$ of families of younger respondents and $27 \%$ of families of older respondents rated these memories as negative or very negative. At the same time, this topic has by far the lowest percentage of positive memories, as only $17 \%$ of families of younger respondents and $33 \%$ of families of older respondents evaluated these memories as positive or very positive. The results of the survey give rise to the conclusion that older respondents valued memories from all categories much more positively than younger respondents. Likewise, we can conclude that nostalgia for the former country only rarely includes longing for the previous political arrangement and system, whereas its socio-economic advantages were much more strongly missed. It is these socio-economic conditions that older respondents evaluated much more positively than did younger respondents, even though the first part of the survey showed that some positive memories of economic status and social conditions are passed down more intensely. In this case, it shows very clearly that socio-economic factors cannot be reduced to black-andwhite, but come in a whole range of shades in between. Consequently, Yugonostalgia also cannot be general- ized as missing "the good old days". Memories about their experiences which were recalled by family members, especially in the circles of older people, were also predominantly positive, and older respondents also often mentioned experiences in their youth, unimpeded travel around the republics of the former joint country, vacationing, socializing and similar when answering open-ended questions.

That a positive image of everyday life in Yugoslavia is being passed down to younger generations is confirmed by the responses of both younger as well as older respondents. The majority of the group of younger respondents $(75 \%)$ responded affirmatively to the question of whether, based on the testimony of older generations, life was better in Yugoslavia. Only 11\% of younger respondents responded negatively, while the remaining $14 \%$ had difficulty providing an unequivocal answer since their opinion was that the judgment depended on the personal experience of the interlocutor or the sphere of life evaluated by them. The answers of the older respondents were very similar when asked if life was better in Yugoslavia. 69\% answered affirmatively, $14 \%$ negatively, and the remainder did not want to generalize since the experience differed for different groups of people and spheres of life.

In the concluding part of the study, we were also interested in what traces of the Yugoslav past respondents come into contact with in their current everyday life. They most frequently mentioned monuments and symbols of the former country (34\%), followed by cultural aspects $(18 \%$ - most often music and films). More than a tenth of respondents see the legacy of Yugoslavia in the multi-ethnicity of Slovenia or in politi-

politics and political conditions in Yugoslavia - younger

politics and political conditions in Yugoslavia - older

social and economic conditions in Yugoslavia - younger

social and economic conditions in Yugoslavia - olde

sporting achievements of Yugoslav athletes - younger

sporting achievements of Yugoslav athletes - older

experiences of family members from Yugoslav times - younger

experiences of family members from Yugoslav times - older

other topics - younger

other topics - older
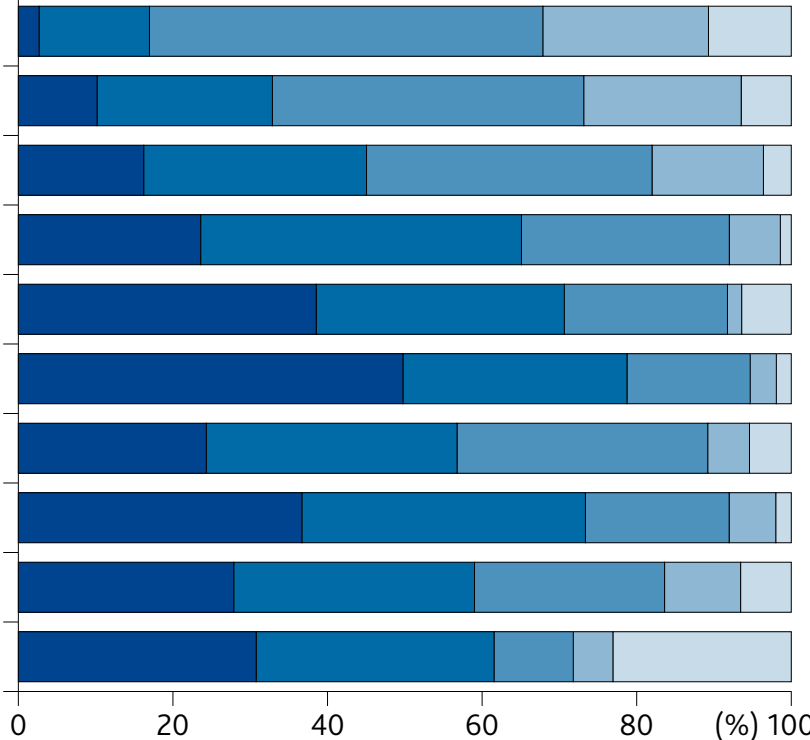

0

20

negative

very negative

very positive $\square$ positive $\square$ neither positive or negative

Figure 4. Assessment of memories of selected topics in the families of older and younger respondents 
cal divides. Both groups of respondents mentioned political divides, including divergent views of historical events during the Second World War and its aftermath (the domobranci or Slovene Home Guard and the Partisans, emigration, postwar mass graves, etc.). On the other hand there were noticeable intergenerational differences in that younger respondents more often highlighted observations of Yugoslav cultural elements (24\%) and multi-ethnicity in Slovenia (15\% of younger respondents as compared to $9 \%$ of older ones), while older respondents more frequently cited monuments and symbols (36\% of older compared to $30 \%$ of younger) and offered numerous diverse other responses $(19 \%)$ that could not be classified in the other categories. Older respondents cited public education and health, affordable housing, remnants of the mentality on the role of the state and its responsibility to care for the individual, memories of the past and in particular also (Yugo)nostalgia as the legacy of the past.

As Pečjak noted back in 2005, the appeal of nostalgia lies precisely in the fact that something no longer exists, that it remains as a past that one cannot return to, that it is lost forever; that it is safely stored and discovered as needed in the present; because it is cleansed of the bad, it exists as an ideal, a model, and a legitimate measure of human behavior and activity in the present (Pečjak, 2005). Anderson has written that "like memory, nostalgia is an evasive concept of often-ambiguous meaning" (Anderson, 2005). And although things from the past, as Nietzsche says, are never "viewed in their true per- spective or receive their just value; but value and perspective change with the individual or the nation that is looking back on its past" (Nietzsche, 1957, 19), instead of remembering accurately what happened, we attempt to make the past understandable in relation to the present situation (Anderson, 2005). In his book on Titostalgia, Velikonja wrote that one of the most important functions of nostalgia, whether personal or collective, is the creation - and not merely the restoration or embellishment - of a kind of past that "in fact never existed, and is what it is only in present perceptions or desires of what was good at that time" (Velikonja, 2008b). In his view nostalgia is based on utopias of the past, in which people mourn not "for the true past but for the desires and visions of that time, for old glory; therefore what is being missed are former dreams, not real life" (Velikonja, 2008b).

The research did not aim to discuss identity field although a question arises - can we reconcile or connect our memories with the identity or, more precisely, the ethnic identity, which some authors (Waters in Cerulo, 1997) perceive as a product of personal choice - "a social category individuals actively decide to adopt or stress" (Cerulo, 1997)? We might also consider discussing memories in the frame of "collective identity", which is often understood as "a side effect of basic social structures or as a reminder of traditional lifeworlds which would dissolve on the road to modern universalism and global inclusion" (Eisenstadt \& Giesen, 1995).

\section{Conclusion}

Our research successfully sought answers to the research questions set out at the beginning and has clearly shown that positively tinged memories of Yugoslavia predominate in the families of younger as well as older generations. In more than half the families, Yugoslavia was talked about at least occasionally, and more frequently in the families of older respondents. Topics of discussion were most often those relating to social and economic conditions, as well as memories of family members' experiences from Yugoslav times. Least frequent were discussions about the politics and political conditions in Yugoslavia, which respondents in the greatest proportion associated with (very) negative memories. Although memories of the achievements of Yugoslav athletes are slowly fading, they were among the most positively evaluated. While the memories of the older generation are based primarily on personal experience, they are transmitted to younger generations by parents and grandparents, who thus preserve particularly positive memories and along with them
Yugonostalgia, a large part of which can be explained by a sense of loss for certain socio-economic advantages and achievements in Yugoslavia, and certainly also by the personal memories of their youth among older generations. Not least of all, $69 \%$ of respondents older than 30 are convinced that they lived a better life in the former state, and among those younger than 30, 75\% confirmed that older generations testified to a comparatively better life in Yugoslavia. Here it is important to emphasize that in only less than a tenth of respondents might the responses relating to memories and perceptions have been influenced by the fact that they come from families of immigrants from former Yugoslav republics. The influence of family connections might be greater in only a third of respondents, among those whose relatives still live in the territory of the former Yugoslavia. All of this confirms the key finding of our study - Yugonostalgia is nostalgia for something from the past, but it is not a desire to experience or revive that in the present. 


\section{References}

Anderson, D. (2005). Down Memory Lane: Nostalgia for the Old South in Post-Civil War Plantation Reminiscences. The Journal of Southern History, 71(1), 105-136. DOI: $10.2307 / 27648653$

Cerulo, K. A. (1997). Identity Construction: New Issues, New Directions. Annual Review of Sociology, 23, 385-409.

Davis, F. (1979). Yearning for Yesterday: A Sociology of Nostalgia. New York: Free Press.

Eisenstadt, S. N., \& Giesen, B. (1995). The construction of collective identity. European Journal of Sociolo$g y, 36(1), 72-102$.

Fentress, J., \& Wickham, C. (1992). Social Memory. Oxford: Blackwell Publishing Ltd.

Halbwachs, M. (2001). Kolektivni spomin [Collective Memory]. Ljubljana: Studia Humanitatis.

Kiser Anspach, C. (1934). Medical dissertation on nostalgia by Johannes Hofer, 1688. Bulletin of the Institute of the History of Medicine, 2(6), 376-391.

Loftus, E. F., \& Hoffman, H. G. (1989). Misinformation and Memory: The Creation of New Memories. Journal of Experimental Psychology, 118(1), 100-104.

Lowenthal, D. (2015). The Past is a Foreign Country Revisited. Cambridge: Cambridge University Press.

Luthar, B., \& Pušnik, M. (Eds.). (2010). Remembering Utopia: The Culture of Everyday Life in Socialist Yugoslavia, Washington D. C.: New Academia Publishing.

Marušič Kos, M. (2016). Slovenska umetnost in nostalgija po socializmu: elementi, moč in namen zbujanja nostalgije po socializmu $v$ umetnosti poznega socializma ter postsocializma [Slovene art and socialism nostalgia: elements, strength and purpose of socialism nostalgia evoking in late socialism and post socialism art]. Master's thesis. Koper: Univerza na Primorskem, Fakulteta za humanistične študije. Retrieved from: https://share.upr.si/fhs/ PUBLIC/magistrske/Marusic-Kos-Martina.pdf (06.09.2018).

Nietzsche, F. (1957). The Use and Abuse of History. New York: Library of Liberal Arts Press.

Olick, J. K., \& Robbins, J. (1998). Social Memory Studies: From "Collective Memory" to the Historical Sociology of Mnemonic Practices. Annual Review of Sociology, 24(1), 105-140. DOI:https://doi. org/10.1146/annurev.soc.24.1.105

Pečjak, L. (2005). Spomini na Jugoslavijo in jugonostalgija med mladimi [Memories of Yugoslavia and Yugonostalgia among young people]. Graduation thesis. Ljubljana: Univerza v Ljubljani, Fakulteta za družbene vede. Retrieved from: http://dk.fdv.uni-lj. si/dela/Pecjak-Lara.PDF (15.07.2018).
Petrović, T. (2013). The past that binds us: Yugonostalgia as the politics of future. In Pavlović, S., \& Živković, M. (Eds.), Transcending Fratricide: Political Mythologies, Reconciliations, and the Uncertain Future in the Former Yugoslavia (pp. 129-147). Baden Baden: Nomos.

Pickering, M., \& Keightley, E. (2006). The Modalities of Nostalgia. Current Sociology, 54(6), 919-941. DOI: https://doi.org/10.1177/0011392106068458

Rogelj, B. (2006). Nazaj k Evropi - geopolitični diskurzi o Srednji in Vzhodni Evropi v institucijah Evropske unije [Back to Europe - Geopolitical Discourses About Central and Eastern Europe Inside Institutions of European Union]. Dela, 26, 181-202. DOI: https://doi.org/10.4312/dela.26.181-202

Rogelj, B., Vintar Mally, K., \& Resnik Planinc, T. (2017). "Yugonostalgia" among young Slovenes. In Mentz, O., \& Mckay, T. (Eds.), Unity in Diversity: European Perspectives on Borders and Memories (pp. 133 149). Zürich: LIT Verlag.

Todorova, M., \& Gille, Z. (Eds.). (2010). Post-Communist Nostalgia. New York, Oxford: Berghahn Books.

Todorova, M., Dimou, A., \& Troebst, S. (Eds.). (2014). Remembering Communism - Private and Public Recollections of Lived Experience in Southeastern Europe, Budapest, New York: Central European University Press.

Velikonja, M. (2004). Tistega lepega dne: Značilnosti sodobnega nostalgičnega diskurza [That beautiful day: Characteristics of modern nostalgic discourse]. Bal Canis, 5(12/16), 37-40.

Velikonja, M. (2008a). "Red shades": Nostalgia for socialism as an element of cultural pluralism in the Slovenian transition. Slovene Studies, 30(2), 171-184. Velikonja, M. (2008b). Titostalgija - Śtudija nostalgije po Josipu Brozu [Titostalgia - A study of nostalgia for Josip Broz]. Ljubljana: Mirovni inštitut. Retrieved from: http://mediawatch.mirovni-institut.si/edicija/seznam/20/mediawatch20.pdf (05.09.2018).

Wertsch, J. V., \& Roediger III, H. L. (2008). Collective memory: Conceptual foundations and theoretical approaches. Memory, 16(3), 318-326.

Wieliczko, B., \& Zuk, M. (2003). Post-Communist Nostalgia Among the Middle-Aged Middle-Class Poles. Paper presented at the annual meeting of the American Sociological Association, Atlanta Hilton Hotel, Atlanta, GA, Aug 16, 2003. Retrieved from: http://citation.allacademic.com/meta/p_mla_apa_ research_citation/1/o/6/7/o/p106706_index.html (22.08.2018).

Zerubavel, E. (1996). Social Memories: Steps to a Sociology of the Past. Qualitative Sociology, 19(3), 283-299. 
Internet 1: Cambridge Dictionary https://dictionary.cambridge.org/dictionary/english/nostalgia (01.09.2018).
Internet 2: Merriam Webster Dictionary https:// www.merriam-webster.com/dictionary/nostalgia (01.09.2018).

Internet 3: SSKJ http://bos.zrc-sazu.si/cgi/neva.exe ? name $=$ ssbsj\&tch $=14 \&$ expression $=z s \% 3 D_{42} 293$ (01.09.2018). 